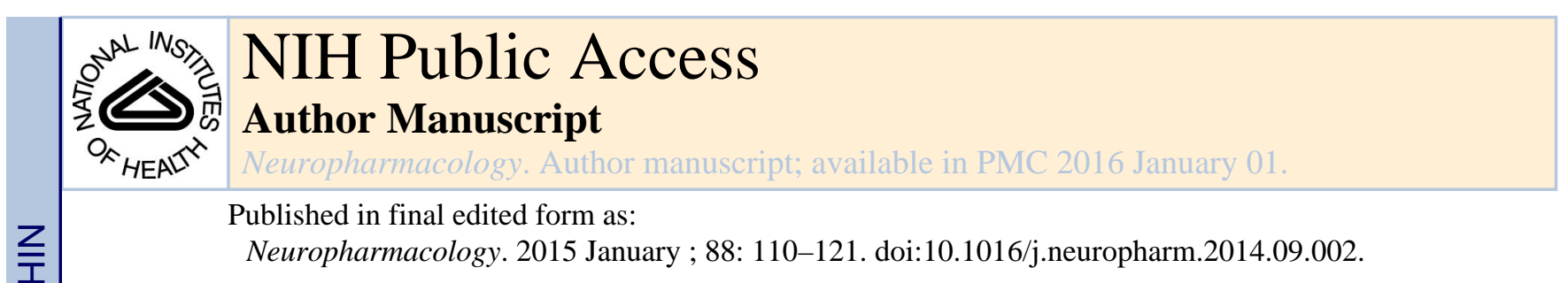

\title{
ALPHA-1 ADRENORECEPTORS MODULATE GABA RELEASE ONTO VENTRAL TEGMENTAL AREA DOPAMINE NEURONS
}

\author{
M.C. Velásquez-Martínez ${ }^{\mathrm{a}, \mathrm{b}}$, R. Vázquez-Torres ${ }^{\mathrm{a}}$, L.V. Rojas ${ }^{\mathrm{c}}$, P. Sanabria ${ }^{\mathrm{c}}$, and C.A. \\ Jiménez-Rivera ${ }^{\mathrm{a}}$ \\ aDepartment of Physiology, Medical Sciences Campus, University of Puerto Rico, San Juan - \\ Puerto Rico. \\ bLaboratorio de Neurociencias y Comportamiento, Departamento de Ciencias Básicas, Facultad \\ de Salud, Universidad Industrial de Santander. Bucaramanga, Colombia.
}

'Department of Physiology, Universidad Central del Caribe, Bayamón - Puerto Rico.

\begin{abstract}
The ventral tegmental area (VTA) plays an important role in reward and motivational processes involved in drug addiction. Previous studies have shown that alpha1-adrenoreceptors (a1-AR) are primarily found presynaptically at this area. We hypothesized that GABA released onto VTAdopamine (DA) cells is modulated by presynaptic a1-AR. Recordings were obtained from putative VTA-DA cells of male Sprague-Dawley rats (28-50 days postnatal) using whole-cell voltage

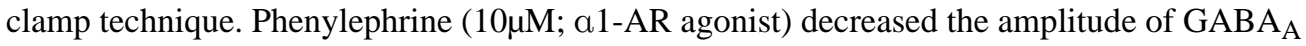
receptor-mediated inhibitory postsynaptic currents (IPSCs) evoked by electrical stimulation of afferent fibers $(n=7 ; p<0.05)$. Prazosin $(1 \mu \mathrm{M}, \alpha 1-\mathrm{AR}$ antagonist $)$, blocked this effect. Paired-pulse ratios were increased by phenylephrine application $(n=13 ; \mathrm{p}<0.05)$ indicating a presynaptic site of action. Spontaneous IPSCs frequency but not amplitude, were decreased in the presence of phenylephrine $(n=7 ; p<0.05)$. However, frequency or amplitude of miniature IPSCs were not changed $(n=9 ; p>0.05)$. Phenylephrine in low $\mathrm{Ca}^{2+}(1 \mathrm{mM})$ medium decreased IPSC amplitude $(\mathrm{n}=7 ; \mathrm{p}<0.05)$. Chelerythrine (a protein kinase $\mathrm{C}$ inhibitor) blocked the a1-AR action on IPSC amplitude $(n=6 ; p<0.05)$. Phenylephrine failed to decrease IPSCs amplitude in the presence of paxilline, a BK channel blocker $(n=7 ; p<0.05)$. Taken together, these results demonstrate that a1ARs at presynaptic terminals can modulate GABA release onto VTA-DA cells. Drug-induced changes in a1-AR could contribute to the modifications occurring in the VTA during the addiction process.
\end{abstract}

(C) 2014 Elsevier Ltd. All rights reserved.

Corresponding author: C.A. Jiménez-Rivera. Department of Physiology, Medical Sciences Campus, Main Building, $6^{\text {th }}$ floor. San Juan, Puerto Rico, PR 00936. Tel: +1 787758 2525. carlos.jimenez8@upr.edu.

Publisher's Disclaimer: This is a PDF file of an unedited manuscript that has been accepted for publication. As a service to our customers we are providing this early version of the manuscript. The manuscript will undergo copyediting, typesetting, and review of the resulting proof before it is published in its final citable form. Please note that during the production process errors may be discovered which could affect the content, and all legal disclaimers that apply to the journal pertain. 


\section{Keywords}

Dopamine neurons; GABA release; alpha1-adrenoreceptor; Ventral Tegmental Area

\section{INTRODUCTION}

The mesocorticolimbic system is composed of dopamine (DA) neurons projecting mainly from the ventral tegmental area (VTA) to cortical and ventral forebrain structures (Dahlstrom and Fuxe, 1964, Ungerstedt, 1971, Lammel et al., 2011). Activation of VTA DA neurons has been implicated in motivated behaviors as well as in mediating the reinforcing actions of drugs of abuse (Schultz, 2002, Kauer, 2004, Grace et al., 2007).

VTA DA neurons receive noradrenergic (NE) inputs from locus coeruleus and other pontine structures (Jones et al., 1977, Mejias-Aponte et al., 2009) and tracing studies have shown that NE afferents have extrasynaptic and synaptic connections on VTA DA neurons (Liprando et al., 2004). Moreover, the VTA contains alpha-1 adrenoreceptors (a1-ARs) (Greene et al., 2005) which are located primarily in pre-synaptic elements (Rommelfanger et al., 2009). Noradrenergic (NE) inputs have been shown to facilitate VTA DA neuronal transmission and induce changes in burst firing via a1 adrenergic receptors (a1-ARs) (Grenhoff et al., 1993, Grenhoff and Svensson, 1993, Grenhoff et al., 1995, Paladini and Williams, 2004). Also, a1-ARs participate in the development of stress and anxiety responses, and in addiction-related behaviors (Cecchi et al., 2002, Hague et al., 2003, Jimenez-Rivera et al., 2006, Greenwell et al., 2009).

The VTA receives considerable inhibitory inputs mainly in the form of GABAergic innervation from the mesopontine tegmentum, the lateral habenula via the rostromedial tegmentum (RMTg), nucleus accumbens (NAcc) and the periaqueductal gray (Jhou et al., 2009a, Jhou et al., 2009b). Changes in GABAergic input on VTA DA neurons can control their firing patterns (Paladini and Tepper, 1999, Lobb et al., 2010). For example, decreased GABAergic inhibition contributes to the generation of bursts in DA neurons (Jhou et al., 2009a, Lobb et al., 2011, Morikawa and Paladini, 2011). Since bursting firing has been related to enhance neurotransmitter release (Floresco et al., 2003), modulation of DA neuronal bursting activity is one mechanisms that can modify DA release in VTA rewardrelated projections.

Pharmacological stimulation of a1-ARs induces changes in GABA-mediated synaptic transmission in different brain areas. This a1-ARs-mediated effect has been evidenced in different brain structures such as the hippocampus, frontal cortex, ventrolateral BNST, cerebellar, pyriform, and enthorrinal cortices, basolateral amygdala (BLA), septal and septohippocampal area (Mouradian et al., 1991, Alreja and Liu, 1996, Bergles et al., 1996, Marek and Aghajanian, 1996, Kawaguchi and Shindou, 1998, Braga et al., 2004, Dumont and Williams, 2004, Herold et al., 2005, Lei et al., 2007, Hillman et al., 2009). The control of GABA neurotransmission onto VTA DA neurons could have important implications, however, up to our knowledge, there is no direct evidence demonstrating such mechanism. The results in this work using brain slices demonstrate the modulatory role of presynaptic a1-ARs activation on the GABA release onto VTA DA neurons. 


\section{METHODS}

\section{Animals}

All experimental procedures were performed according to the US Public Health Service publication "Guide for the Care and Use of Laboratory Animals" and were approved by the Animal Care and Use Committee at the Universidad Central del Caribe and Medical Sciences Campus - University of Puerto Rico. Electrophysiological experiments were performed with male Sprague-Dawley rats ( $28-50$ days postnatal). Animals were housed two per cage and maintained at constant temperature and humidity with a 12-hr hour light/ dark cycle. Water and food were provided ad libitum.

\section{Electrophysiology}

Sprague-Dawley male rats were anesthetized with a $90 \mathrm{mg} / \mathrm{kg}$ i.p. chloral-hydrate injection of (Sigma, St Louis, MO, USA) and their brains rapidly removed. Midbrain horizontal slices $(220 \mu \mathrm{M})$ containing the VTA were cut using a vibratome (VT1000S, Leica, Germany). The rat midbrain was placed into an ice-cold oxygenated artificial cerebrospinal fluid (ACSF) containing (in mM): $127 \mathrm{NaCl} ; 2.5 \mathrm{KCl} ; 1.25 \mathrm{NaH}_{2} \mathrm{PO}_{4} ; 25 \mathrm{NaHCO}_{3} ; 2 \mathrm{CaCl}_{2} ; 1 \mathrm{MgCl}_{2} ; 25$ $\mathrm{D}(+)$-glucose, and saturated with $95 \% \mathrm{O}_{2}-5 \% \mathrm{CO}_{2}$ gas mixture to a $\mathrm{pH}=7.4$. Slices were transferred to an intermediate chamber and incubated at $32^{\circ}$ in the same solution for 45 -min before the initiation of electrophysiological recordings. MK-801 (10 $\mu \mathrm{M}$, Tocris, Ellisville, MO, USA) was added to the incubation solutions to block $N$-methyl-D-aspartate (NMDA)mediated excitotoxicity (Velasquez-Martinez et al., 2012).

Whole cell voltage clamp recordings were obtained from visually identified neurons in the VTA using an infrared microscope with differential interference contrast (DIC) optics, (BX51WI Olympus, Japan). Recordings were acquired through data acquisition software (pClamp 10, Molecular Devices, Sunnyvale, CA). The VTA was identified as the region lateral to the fasciculus retroflexus and medial to the medial terminal nucleus of the accessory optic tract (MT) (Paxinos and Watson, 2007). Recording from the substantia nigra compacta ( $\mathrm{SNc}$ ), identified as the regions rostral and caudal to the MT, was avoided. All recordings were performed in putative DA neurons identified by the presence of a large hyperpolarization-activated cation current $\left(l_{\mathrm{h}}>200 \mathrm{pA}\right)$, evoked by 1-s hyperpolarizing steps from -60 to $-130 \mathrm{mV}$. $\mathrm{I}_{\mathrm{h}}$ is present in about $84 \%$ VTA DA neurons (Margolis et al., 2006). Therefore, the contribution of non-dopaminergic neurons to the experimental recording performed in this study is likely to be not significant. Whole-cell voltage clamp recordings were made at a holding potential of $-70 \mathrm{mV}$ unless indicated.

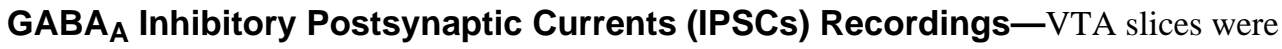
totally submerged in a recording chamber $(500 \mu \mathrm{L})$ with ACSF superfusion at $1-2 \mathrm{ml} / \mathrm{min}$ at $32^{\circ} \mathrm{C}$. Superfusion medium contained 2-amino-5-ph osphonopentanoic acid (AP5; $100 \mu \mathrm{M}$ ) and either 6-cyano-2,3-dihydroxy-7 nitroquinox saline (CNQX; $10 \mu \mathrm{M})$ or 6,7Dinitroquinoxaline-2,3-dione (DNQX; $10 \mu \mathrm{M}$ ) to block fast NMDA- or AMPA- mediated synaptic potentials respectively. In all experiments, eticlopride $(100 \mu \mathrm{M})$ were included in the superfusion solution to block any possible effect mediated by the dopamine D2 receptor. Whole-cell voltage-clamp recordings were made using micropipette filled with a solution 
containing (in mM): $70 \mathrm{~K}$-gluconate, $80 \mathrm{KCI}, 1 \mathrm{EGTA}, 5 \mathrm{HEPES}, 2 \mathrm{MgATP}$, and $0.3 \mathrm{GTP}$. To verify the nature of the current, at the end of each experiment, picrotoxin $(100 \mu \mathrm{M})$ was added to abolish all evoked or spontaneous $\mathrm{GABA}_{\mathrm{A}}$ mediated postsynaptic currents.

Data were collected through a Multiclamp 700B amplifier (Axon Instruments, Foster City, CA, USA), filtered at $1 \mathrm{kHz}$, digitized at $5 \mathrm{kHz}$ using Digidata 1440A (Axon Instruments, Foster City, CA, USA), and stored in a PC computer and analyzed off line using pClamp (v. 10) and final graphs were done using GraphPad Prism 5 (GraphPad Software, Inc) software. Pipette's Liquid junction potential was offset compensated using standard Multiclamp 700B circuitry. The seal's qualities used were 4-6 G $\Omega$. Series resistances were not compensated and were monitored during the entire experiment. Data were discarded if changes of series resistance of more than $15 \%$ occurred.

\section{Recording of Synaptic Currents}

A bipolar stainless steel electrode (FHC Inc, Bowdoin, ME) was placed approximately 100 $\mu \mathrm{m}$ rostral to the recording electrode and used to stimulate afferents at $0.1 \mathrm{~Hz}$ by applying a

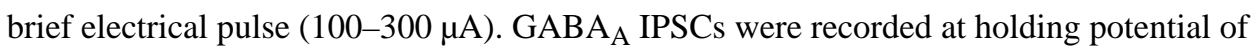
$-70 \mathrm{mV}$. All IPSCs shown in figures were averages of 5 current traces for the treatment under inspection. $\mathrm{GABA}_{\mathrm{A}}$ IPSCs amplitudes were calculated by taking a $1 \mathrm{~ms}$ window around the peak of the IPSC and comparing this to a $5 \mathrm{~ms}$ window immediate before the stimulation artifact. Peak IPSCs amplitudes were averaged during control recordings. This value was used to normalize the following recordings. This procedure allows expressing data as percentages of the control condition for appropriate statistical comparisons. Paired stimuli were given with a $50 \mathrm{~ms}$ interstimulus interval. Paired Pulse Ratio (PPR) was

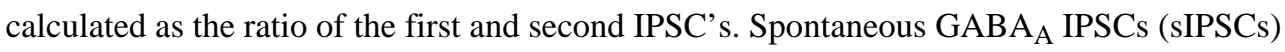
and miniature $\mathrm{GABA}_{\mathrm{A}}$ IPSCs (mlPSCs) were recorded. Tetrodotoxin (TTX, $0.5 \mu \mathrm{M}$, Alomone Laboratories, Jerusalem, Israel) was added to the ACSF to observe the mlPSCs that are independent on the spontaneous presynaptic action potentials. sIPSCs and mIPSCs were recorded at $-70 \mathrm{mV}$ of holding potential, filtered at $1 \mathrm{kHz}$ and digitized at $5 \mathrm{kHz}$ using pCLAMP 10 software (Molecular Devices, Sunnyvale, CA, USA). For a given cell, sIPSCs and mIPSCs were collected (1 sweep for each condition, 3min/sweep) for a control and phenylephrine's period. The recorded sIPSCs and mIPSCs were analyzed afterward using Mini Analysis program 6.0.7 (Synaptosoft Inc. Decatur, GA). Detection criteria were set at $>6 \mathrm{pA},<1.3 \mathrm{~ms}$ rise time, and $<0.1 \mathrm{~ms}$ decay time. The choice of this cutoff amplitude for acceptance of sIPSCs and mIPSCs was made to obtain a high signal-to-noise ratio. Then, each event also was visually inspected to prevent noise disturbance of the analysis.

\section{Drugs}

Phenylephrine hydrochloride ([R]-[-]-1 -[3-Hydroxyphenyl]-2-methylaminoethanol hydrochloride), methoxamine hydrochloride (a-[1-Aminoethyl]-2,5-dimethoxybenzyl alcohol hydrochloride), prazosin hydrochloride (1-[4-Amino-6,7-dimethoxy-2quinazolinyl]-4-[2-furanylcarbonyl]piperazine hydrochloride), chelerythrine chloride (1,2dimethoxy-12-methyl[1,3]benzodioxolo[5,6-c]phenanth ridinium chloride tetrodotoxin citrate) were purchased from Sigma (St Louis, MO, USA). Thapsigargin (3S,3aR,4S,6S, 6AR,7S,8S,9bS)-6- (Acetyloxy)-2,3,3a,4,5,6,6a, 7,8,9b-decahydro-3,3a-dihydroxy-3,6,9- 
trimethyl-8-[[(2Z)-2-methyl-1-oxo-2-butenyl]oxy]-2-oxo-4-(1-oxobutoxy)azuleno[4,5b]furan-7-yl octanoate) was purchased from Tocris (Ballwin, MO). Paxilline was donated from Alomone Laboratories (Jerusalem, Israel). All substances were diluted in fresh ACSF until completely mixed, then transferred to separate graduated reservoirs connected to the chamber. The effects on current amplitude were measured within 5 min after the beginning of the flow (1-2 $\mathrm{ml} / \mathrm{min})$.

\section{Data Analysis}

All data were presented as mean \pm SEM. Statistical significance were assessed using Student's paired t-test, One-Way ANOVA with Newman-Keuls as post hoc analysis except when examining the significance of horizontal shifts to the cumulative probability distribution plots obtained from single cell recordings. For the latter case we used the Kolmogorov-Smirnov (K-S) test. P values were reported throughout the text and significance were set as $\mathrm{p}<0.05$.

\section{RESULTS}

VTA DA neurons seem to be inhibited by both intrinsic and extrinsic sources of GABA (Johnson and North, 1992a, Matsumoto and Hikosaka, 2007, Jhou et al., 2009a). The presence of a1-ARs has been reported in the VTA area (Greene et al., 2005). a1-ARs were found to be primarily localized at pre-synaptic elements in the VTA region (Rommelfanger et al., 2009). However, these studies do not clearly define the synaptic terminal type where a1-ARs are specifically localized; therefore, the presynaptic elements mentioned could be GABAergic terminals.

In order to assess if the activation of a1-ARs alters GABAergic transmission on VTA DA neurons, whole cell recordings of GABA IPSCs were performed on putative DA neurons identified by the presence of a large Ih (>200 pA), slow spontaneous activity and relatively regular inter-spike intervals (Grace and Bunney, 1983, Grace and Onn, 1989). We confirmed that this evoked current was due to $\mathrm{GABA}_{\mathrm{A}}$ receptor activation by blocking the response with the receptor antagonist, picrotoxin $(100 \mu \mathrm{M}$, data not shown).

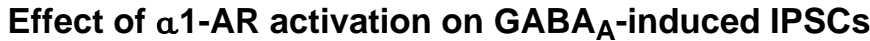

In order to address the question of whether a1-AR activation can modulate GABAergic transmission, we recorded GABA IPSCs amplitude upon the superfusion of the a1-AR agonist phenylephrine. Fig. 1A shows a representative trace where phenylephrine $(10 \mu \mathrm{M})$ superfusion induced a significant reduction in the GABA IPSCs amplitude in a putative VTA DA cell held at $-70 \mathrm{mV}$. The effect was reversible since it returned to near control levels after a washout period. Similarly, superfusion of methoxamine $(40 \mu \mathrm{M})$, another a1AR agonist, significantly decreased GABA IPSCs peak amplitude from $99.46 \pm 2.27 \%$ to $63.87 \pm 8.96 \%$ after 10 minutes' superfusion $\left(n=5\right.$; ANOVA $F_{2,14}=10.06, p<0.005$; Fig 1B). As seen in figure 1B, phenylephrine application resulted in a $\sim 25 \%$ and $30 \%$ reduction in IPSCs amplitudes after 5 (77.4 $\pm 8.6 \%$ of control) and 10 min respectively $(69.1 \pm 8.3 \%$ of control) which was statistically significant ( $\mathrm{n}=7$, ANOVA $\mathrm{F}_{2,18}=6.86, p<0.05$ ). As illustrated in figure $1 \mathrm{C}$, phenylephrine's actions lasted throughout the period of drug 
application (10 $\mathrm{min})$, rapidly returning to pretreatment levels during the washout period (10 min). Phenylephrine's inhibitory action was dose-dependent over the concentration of 0.1 and $100 \mu \mathrm{M}$ (Fig. 1D).

The receptor specificity of phenylephrine-induced inhibition on GABA IPSCs was determined by using prazosin $(1 \mu \mathrm{M})$, an a1-AR antagonist. Prazosin alone, after 10 minutes bath application; did not alter IPSC amplitude when compared to control values (Fig. 2A, B and C; Control $99.4 \pm 1.3 \%$ vs. Prazosin $97.4 \pm 15.3 \%, \mathrm{n}=7$ ). However, when prazosin and phenylephrine were co-superfused for an additional 10 minutes the latter was unable to exert its typical inhibitory action (Prazosin $97.4 \pm 15.3 \%$ vs. Prazosin + Phenylephrine $108.2 \pm 9.2 \%$, ANOVA $_{4,28}=0.84, p>0.05, \mathrm{n}=7$ ). Thus, the phenylephrine-evoked inhibition of GABAergic IPSCs in VTA DA cells seems to be the result of a1-AR activation.

\section{Presynaptic a1-AR activation decreases GABA release on VTA DA neurons}

To determine the synaptic site of action of phenylephrine-induced inhibition of GABA IPSCs, we examined the paired pulse ratio ( $\left.\mathrm{PPR}=\mathrm{IPSC}_{2} / \mathrm{IPSC}_{1}\right)$ before and after phenylephrine superfusion. Fig. A shows the increase in PPR sample recordings after $10 \mu \mathrm{M}$ phenylephrine's superfusion. The PPR increased from $0.99 \pm 0.06$ to $1.17 \pm 0.08$ after 10 minutes phenylephrine's application ( $\mathrm{n}=13$; paired $t$-test, $p<0.01$, Figs. 3B and $\mathrm{C}$ ). These results clearly supports that the activation of a1-ARs evokes IPSCs through a presynaptic decrease in the release probability of GABA.

To further confirm if the observed effects were mediated by presynaptic mechanism we examined changes in the stochastic release, the spontaneous IPSCs (sIPSCs) and the miniature IPSCs (mIPSCs) before and after phenylephrine's (10 $\mu \mathrm{M})$ administration. Sample recordings before (control) and after the agonist's application (Fig. 4A) showed that there was a reduction in the frequency but not in the amplitude of sIPSCs. Phenylephrine decreased the frequency of these events from $0.89 \pm 0.12$ to $0.53 \pm 0.12 \mathrm{~Hz}$ (paired t-test, $\mathrm{p}<0.05, \mathrm{n}=7$; Fig 4D) while the mean amplitude of sIPSCs population before and during phenylephrine application was $51.68 \pm 3.77$ and $50.41 \pm 3.2 \mathrm{pA}$, respectively (paired t-test, $\mathrm{p}=0.68, \mathrm{n}=7$; Fig $4 \mathrm{D}$ ). These findings were further supported by their respective cumulative probability distributions. In particular, a right shift was observed in the inter-event interval distribution (reduction in frequency) but no change was seen in the amplitude distribution (Fig. 4B and C). Consequently, the results support a presynaptic modulation of a1-ARactivation reducing GABAergic neurotransmission on VTA DA neurons.

In order to test whether phenylephrine effects were only due to an action-potential dependent mechanism we measured changes in miniature IPSCs (mlPSCs) in the presence of TTX $(0.5 \mu \mathrm{M})$. Under these conditions, sample recordings before and after 10 minutes phenylephrine's application showed that there was no change in the mIPSC frequency or amplitude (Fig. 5A). The inter-event intervals probability and amplitude distribution demonstrated no significant changes after 10 minutes phenylephrine's application (Figs. 5B and $\mathrm{C}$, respectively). Population analysis illustrate that phenylephrine did not produce significant changes in frequency (from $1.10 \pm 0.15$ to $1.07 \pm 0.19 \mathrm{~Hz}, \mathrm{n}=9$, paired $t$-test $p=0.69$, Fig. 5D), or amplitude (from $34.11 \pm 5.36$ to $30.94 \pm 4.14 \mathrm{pA}, \mathrm{n}=9$, paired $t$-test 
$p=0.19$, Fig. 5D) compared to control recordings. Altogether, these results support the notion that a1-AR effect on GABA release on VTA DA neurons is action potential-dependent.

\section{a1-ARs modulatory effect on GABA release is independent of both intra and extracellular calcium}

To test if extracellular calcium was involved in the observed a1-ARs effects, we reduced the calcium concentration of the ACSF from $2.0 \mathrm{mM}$ to $1.0 \mathrm{mM}$ to limit the calcium influx to the presynaptic terminal. Fig. 6A shows sample traces of GABA IPSCs before and after phenylephrine's administration in the presence of a reduced calcium concentration. Phenylephrine, in $1.0 \mathrm{mM}$ calcium, decreased the GABA IPSCs amplitude $(75.58 \pm 7.68 \%$ of control, $n=7$, ANOVA $F_{2,18}=5.39, p<0.05$, Fig. $6 \mathrm{~B}$ and $\mathrm{C}$ ). Therefore, these results suggest that a1-AR effect on GABA release on VTA DA neurons is independent of extracellular calcium concentration.

We also, explored whether intracellular calcium stores participated in the a1-ARs mediated effect. Brain slices were pre-incubated in thapsigargin $(10 \mu \mathrm{M} ; 30 \mathrm{~min})$ which depletes intracellular $\mathrm{Ca}^{2+}$ stores by blocking the ATPase that mediates $\mathrm{Ca}^{2+}$ uptake (Thastrup et al., 1990, Mathew and Hablitz, 2008). Thapsigargin did not block phenylephrine's effect on GABA $_{\mathrm{A}}$ IPSCs amplitude $\left(71.31 \pm 8.22 \%\right.$ of control, $\mathrm{n}=8$, ANOVA $\mathrm{F}_{2,23}=4.24, \mathrm{p}<0.05$, Fig. 6D). These results suggest that intracellular $\mathrm{Ca}^{2+}$ stores are not involved in the a1-AR effect on $\mathrm{GABA}_{\mathrm{A}}$ IPSCs in VTA DA neurons.

\section{a1-AR-mediated decrease in GABA release through PKC pathway}

Protein Kinase C (PKC) has been shown to be a downstream element in the intracellular signaling pathway of a1-AR activation (Tamura et al., 1993). Therefore, the effect of a1AR on GABA release could be mediated by direct coupling via PKC. To explore whether PKC is required for the a1-AR mediated presynaptic GABA release, brain slices were superfused with the membrane-permeable PKC inhibitor chelerythrine $(1 \mu \mathrm{M})$. Phenylephrine's application after 10 minutes of chelerythrine superfusion failed to induce changes on GABA ISPCs peak amplitude (control: $100.42 \pm 1.72 \%$; chelerythrine 10 min:

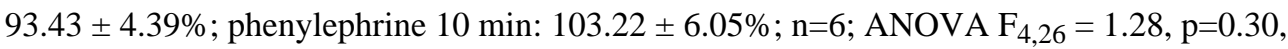
Fig. 7).

\section{a1-AR-mediated decrease in GABA release involves BK channels activation}

Activation of BK channels induces a potassium outward current in response to a membrane depolarization (Vandael et al., 2010). Therefore, BK channel activation could induce a membrane hyperpolarization and decrease neurotransmitter release. To explore if BK channels were involved in a1-AR mediated presynaptic GABA release, slices were superfused with paxilline $(1 \mu \mathrm{M})$, a selective BK channel inhibitor. After 10 minutes of paxilline superfusion $(96.76 \pm 3.97 \%$ of control), phenylephrine failed to induce a decrease on $\mathrm{GABA}_{\mathrm{A}}$ IPSCs $\left(100.71 \pm 2.17 \%\right.$ of control, $\mathrm{n}=7$, ANOVA $\mathrm{F}_{4,31}=0.83$, $\mathrm{p}=0.51$, Fig. 8$)$. These results indicate that $\mathrm{BK}$ channel stimulation is required to reduce GABA release on VTA DA neurons caused by a1-AR activation. 


\section{DISCUSSION}

\section{GABA RELEASE MODULATION BY a1-AR ONTO VTA DA NEURONS}

Our studies demonstrate that a1-ARs modulate GABA neurotransmission onto VTA DA

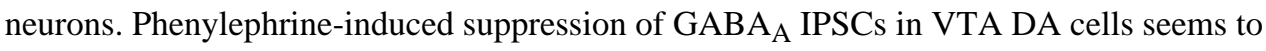
be a1-ARs selective since prazosin (a1-AR antagonist) blocked phenylephrine's inhibitory actions on IPSCs. Furthermore, a paired-pulse ratio analysis and an evaluation of sIPSCs recordings indicated that the a1-ARs' inhibitory effect was mediated by activation of a presynaptic receptor mechanism. Moreover, the a1-AR modulatory effect on GABA transmission requires presynaptic action potentials, the selective activation of a PKC intracellular pathway and recruitment of BK channels. However, it seems that a1-ARs' effect on GABA release does not require the presence of either intra or extracellular calcium since it was still present in experiments with low intra and extracellular calcium. Because any manipulation of external calcium can alter GABA release indirectly, it is difficult to completely rule out a role of calcium on the phenylephrine-induced reduction in GABA transmission.

DA neurons seem to be inhibited by both intrinsic and extrinsic GABA sources (Johnson and North, 1992a, Matsumoto and Hikosaka, 2007, Jhou et al., 2009b). GABAergic synaptic afferents to VTA DA cells have been identified arising from the rostromedial tegmental nucleus (RMTg), nucleus accumbens shell, ventral pallidum, periaqueductal gray (PAG) and laterodorsal tegmentum (LDT) (Kalivas et al., 1993, Geisler and Zahm, 2005, Jhou et al., 2009a, Sesack and Grace, 2010, Morikawa and Paladini, 2011).

Immunoreactivity for GABA terminals forming symmetric synapses with dendritic shafts of VTA neurons has been described (Charara et al., 1996). A considerable majority of RMTg axons in the VTA form synapses with dendrites of DA cells (Balcita-Pedicino et al., 2011). Moreover, neighboring GABA neurons can innervate DA cells through local connections (Johnson and North, 1992b, Nugent and Kauer, 2008, Omelchenko and Sesack, 2009).

a1-ARs modulation of GABA-mediated synaptic transmission have been described in several brain structures. Presynaptic a1-ARs' activation mediates inhibition of GABAreleasing cells in rat hippocampal cultures, auditory cortex, cerebellum and spinal dorsal horn neurons (Mouradian et al., 1991, Croce et al., 2003, Yuan et al., 2009, Salgado et al., 2011).

We initially assessed the synaptic site of phenylephrine's action on GABAergic transmission on VTA DA neurons using the PPR protocol. A variation in PPR is associated with changes in presynaptic release probability. An increase in PPR typically indicates a decrease in the probability of neurotransmitter release (Zucker, 1989). Our results showed that a1-ARs activation increases the PPR thus, they strongly support that a1-ARs are localized presynaptically to VTA DA neurons. In accordance to our data a recent immunohistochemical study showed that a1-ARs are co-localized with GABA-positive terminals in the VTA thus providing the locus for the observed interaction (Mitrano et al., 2012). 
Changes in SIPSC activity induced by a1-ARs activation have been reported in different brain structures. Croce et al (Croce et al., 2003) demonstrated that NE has an inhibitory effect on GABA-releasing cells in the rat's hippocampus. The NE's inhibitory action was due to a1-ARs activation since superfusion of the a1-ARs agonist, cirazoline, reduced the frequency of sIPSCs and mIPSCs recorded from cultured hippocampal cells. Such results suggest that a1-ARs activation decreases GABA neurotransmission via a presynaptic mechanism. Similarly, our results showed that a1-ARs activation decreases GABA $\mathrm{A}$ sIPSCs frequency but not the amplitude in VTA DA cells. Also, our data suggest that the decrease in GABA release induced by a1-ARs activation is dependent on presynaptic action potentials, since in the presence of TTX, changes in mIPSCs were absent. In contrast, NE activation of a1-ARs increases GABA $_{A}$-IPSC frequency in vlBNST neurons, cerebellar Purkinje cells, hippocampal CA1 pyramidal cells and interneurons in piriform cortex (Marek and Aghajanian, 1996, Dumont and Williams, 2004, Herold et al., 2005, Hillman et al., 2009). These studies indicate that a1-ARs present on presynaptic terminals, once activated, can also increase GABA release. Altogether, the above data suggest that a1-ARs modulation of GABA release in the CNS is complex.

Protein kinase $\mathrm{C}(\mathrm{PKC})$, a phospholipid-dependent serine/threonine kinase, appears to be involved in the signal transduction response activated by many neurotransmitters (Olive and Newton, 2010, Kang et al., 2012). The PKC family is divided into three subcategories according to their structure, calcium-activation dependence and lipid activators. The conventional PKCs (cPKCs, $\alpha, \beta \mathrm{I}$, ( $\beta \mathrm{II}$, and $\gamma$ ) are activated by calcium and by the lipid signaling intermediate diacylglycerol (DAG). Novel PKCs (nPKCs, $\delta, \varepsilon, \eta$, and $\theta$ ) are activated by DAG but not by calcium. Atypical PKCs (aPKCs, $\zeta$ and $\lambda / 1$ ) require neither DAG nor calcium and are instead activated by lipids such as phosphatidic and arachidonic acid (Hirai and Chida, 2003, Olive and Newton, 2010, Zeng et al., 2012). a1-ARs are Gqcoupled receptors that induce PKC activation. Our results showed that chelerythrine superfusion (a specific PKC inhibitor) blocked phenylephrine's inhibitory action on IPSCs amplitude. Thus, a1-ARs modulation of GABA neurotransmission onto VTA DA cells, similarly to a1-ARs presynaptic changes of glutamate neurotransmission, uses a PKCdependent pathway (Velasquez-Martinez et al., 2012). However, since a1-AR effect on GABA IPSCs is still present in low calcium ACSF and under intracellular calcium depletion using thapsigargin, we suggest that the PKC subtype activated by a1-AR-Gq-mediated pathway is probably the PKC $\delta$ subtype. Studies using specific PKC $\delta$ blockers need to be carried out to directly test this hypothesis.

The BK channels are large conductance voltage and $\mathrm{Ca}^{2+}$ activated $\mathrm{K}^{+}$channels. These channels are sensitive to voltage-gated calcium channels (VGCC) and to increases in intracellular calcium (Marrion and Tavalin, 1998, Vergara et al., 1998, Lee and Cui, 2010). BK channel activation induces membrane hyperpolarization by $\mathrm{K}^{+}$efflux from the cell and reduces intracellular $\mathrm{Ca}^{2+}$ by closing VGCC (Hu et al., 2001, Wang, 2008, Cui, 2010). These BK mechanisms, namely membrane hyperpolarization and reduction of intracellular $\mathrm{Ca}^{2+}$, have been associated to neurotransmitter release modulation in different brain areas (Hu et al., 2001, Raffaelli et al., 2004, Wang, 2008, Martire et al., 2011). 
PKC regulation of BK channels has been previously described. PKC can increase the activity of BK channels reconstituted in lipid bilayers (Reinhart and Levitan, 1995), present in COS7 cells (Kim and Park, 2008) or in the CA3 region of hippocampal slice cultures (Raffaelli et al., 2004). Specifically, PKC $\delta$, has been related to BK channel activation (Kim and Park, 2008). Therefore, a1-ARs could exert their effects by a PKC $\delta$ stimulation which in turns phosphorylates and increases BK channel function allowing synaptic terminal hyperpolarization. This hyperpolarization will decrease GABA release. Our results demonstrated that in the presence of paxilline, a BK channel inhibitor, the a1-AR-mediated decrease in GABA IPSCs amplitude was blocked. Therefore, BK channel activation seems to exert an important role in a1-ARs effect on GABA release onto VTA DA neurons.

Stimulation of GABA-RMTg neurons increases the IPSC amplitude in VTA DA cells that project to the NAcc lateral shell (Lammel et al., 2012). The VTA DA - NAcc lateral shell connection is highly associated with reward behavior (Bromberg-Martin et al., 2010, Lammel et al., 2011). Activation of GABA neurons within the VTA has been linked with a disruption of reward (van Zessen et al., 2012). Taken together, these data suggest that activation of GABA-RMTg inputs or local VTA GABA neurons can induce an inhibition of VTA DA cells which in turn will modulate reward-related behaviors. Consequently, a decrease in these two inhibitory sources onto VTA DA cells can facilitate the development of reward behaviors.

In conclusion, the present results demonstrated that a1-ARs activation decreases GABAergic neurotransmission presynaptically onto VTA DA neurons (Fig 9). a1-ARsmediated modulation of GABA release may play an important role in the development of cocaine addiction by reducing the inhibitory inputs onto VTA DA neurons (Bocklisch et al., 2013). Further evaluation of the mechanism presented here could prove to be relevant for new therapeutic interventions.

\section{Acknowledgments}

This work was funded by MBRS-SCORE (GM-08224) to C.A.J.R.M.C.V.M received economical support from Universidad Industrial de Santander, Colombia. This work was supported in part by the Research Centers for Minority Institution to Medical Sciences Campus - UPR (RCMI/NIH Grant No. G12RR03051) and to Universidad Central del Caribe (RCMI/NHI Grant No. 8G12MD007583). We are grateful for the donation of paxilline from Alomone Laboratories (Jerusalem, Israel).

\section{REFERENCES}

Alreja M, Liu W. Noradrenaline induces IPSCs in rat medial septal/diagonal band neurons: involvement of septohippocampal GABAergic neurons. J Physiol. 1996; 494(Pt 1):201-215. [PubMed: 8814616]

Balcita-Pedicino JJ, Omelchenko N, Bell R, Sesack SR. The inhibitory influence of the lateral habenula on midbrain dopamine cells: ultrastructural evidence for indirect mediation via the rostromedial mesopontine tegmental nucleus. J Comp Neurol. 2011; 519:1143-1164. [PubMed: 21344406]

Bergles DE, Doze VA, Madison DV, Smith SJ. Excitatory actions of norepinephrine on multiple classes of hippocampal CA1 interneurons. J Neurosci. 1996; 16:572-585. [PubMed: 8551341]

Bocklisch C, Pascoli V, Wong JC, House DR, Yvon C, de Roo M, Tan KR, Luscher C. Cocaine disinhibits dopamine neurons by potentiation of GABA transmission in the ventral tegmental area. Science. 2013; 341:1521-1525. [PubMed: 24072923] 
Braga MF, Aroniadou-Anderjaska V, Manion ST, Hough CJ, Li H. Stress impairs alpha(1A) adrenoceptor-mediated noradrenergic facilitation of GABAergic transmission in the basolateral amygdala. Neuropsychopharmacology. 2004; 29:45-58. [PubMed: 14532911]

Bromberg-Martin ES, Matsumoto M, Hikosaka O. Dopamine in motivational control: rewarding, aversive, and alerting. Neuron. 2010; 68:815-834. [PubMed: 21144997]

Cecchi M, Khoshbouei H, Javors M, Morilak DA. Modulatory effects of norepinephrine in the lateral bed nucleus of the stria terminalis on behavioral and neuroendocrine responses to acute stress. Neuroscience. 2002; 112:13-21. [PubMed: 12044468]

Charara A, Smith Y, Parent A. Glutamatergic inputs from the pedunculopontine nucleus to midbrain dopaminergic neurons in primates: Phaseolus vulgaris-leucoagglutinin anterograde labeling combined with postembedding glutamate and GABA immunohistochemistry. J Comp Neurol. 1996; 364:254-266. [PubMed: 8788248]

Croce A, Astier H, Recasens M, Vignes M. Opposite effects of alpha 1- and beta-adrenoceptor stimulation on both glutamate- and gamma-aminobutyric acid-mediated spontaneous transmission in cultured rat hippocampal neurons. J Neurosci Res. 2003; 71:516-525. [PubMed: 12548707]

Cui J. BK-type calcium-activated potassium channels: coupling of metal ions and voltage sensing. J Physiol. 2010; 588:4651-4658. [PubMed: 20660558]

Dahlstrom A, Fuxe K. Localization of monoamines in the lower brain stem. Experientia. 1964; 20:398-399. [PubMed: 5856530]

Dumont EC, Williams JT. Noradrenaline triggers GABAA inhibition of bed nucleus of the stria terminalis neurons projecting to the ventral tegmental area. J Neurosci. 2004; 24:8198-8204. [PubMed: 15385602]

Floresco SB, West AR, Ash B, Moore H, Grace AA. Afferent modulation of dopamine neuron firing differentially regulates tonic and phasic dopamine transmission. Nat Neurosci. 2003; 6:968-973. [PubMed: 12897785]

Geisler S, Zahm DS. Afferents of the ventral tegmental area in the rat-anatomical substratum for integrative functions. J Comp Neurol. 2005; 490:270-294. [PubMed: 16082674]

Grace AA, Bunney BS. Intracellular and extracellular electrophysiology of nigral dopaminergic neurons--3. Evidence for electrotonic coupling. Neuroscience. 1983; 10:333-348. [PubMed: 6633865]

Grace AA, Floresco SB, Goto Y, Lodge DJ. Regulation of firing of dopaminergic neurons and control of goal-directed behaviors. Trends Neurosci. 2007; 30:220-227. [PubMed: 17400299]

Grace AA, Onn SP. Morphology and electrophysiological properties of immunocytochemically identified rat dopamine neurons recorded in vitro. J Neurosci. 1989; 9:3463-3481. [PubMed: 2795134]

Greene JG, Dingledine R, Greenamyre JT. Gene expression profiling of rat midbrain dopamine neurons: implications for selective vulnerability in parkinsonism. Neurobiol Dis. 2005; 18:19-31. [PubMed: 15649693]

Greenwell TN, Walker BM, Cottone P, Zorrilla EP, Koob GF. The alpha1 adrenergic receptor antagonist prazosin reduces heroin self-administration in rats with extended access to heroin administration. Pharmacol Biochem Behav. 2009; 91:295-302. [PubMed: 18703080]

Grenhoff J, Nisell M, Ferre S, Aston-Jones G, Svensson TH. Noradrenergic modulation of midbrain dopamine cell firing elicited by stimulation of the locus coeruleus in the rat. J Neural Transm Gen Sect. 1993; 93:11-25. [PubMed: 8373553]

Grenhoff J, North RA, Johnson SW. Alpha 1-adrenergic effects on dopamine neurons recorded intracellularly in the rat midbrain slice. Eur J Neurosci. 1995; 7:1707-1713. [PubMed: 7582125]

Grenhoff J, Svensson TH. Prazosin modulates the firing pattern of dopamine neurons in rat ventral tegmental area. Eur J Pharmacol. 1993; 233:79-84. [PubMed: 8097162]

Hague C, Chen Z, Uberti M, Minneman KP. Alpha(1)-adrenergic receptor subtypes: non-identical triplets with different dancing partners? Life Sci. 2003; 74:411-418. [PubMed: 14609720]

Herold S, Hecker C, Deitmer JW, Brockhaus J. alpha1-Adrenergic modulation of synaptic input to Purkinje neurons in rat cerebellar brain slices. J Neurosci Res. 2005; 82:571-579. [PubMed: 16237725] 
Hillman KL, Lei S, Doze VA, Porter JE. Alpha-1A adrenergic receptor activation increases inhibitory tone in CA1 hippocampus. Epilepsy Res. 2009; 84:97-109. [PubMed: 19201164]

Hirai T, Chida K. Protein kinase Czeta (PKCzeta): activation mechanisms and cellular functions. J Biochem. 2003; 133:1-7. [PubMed: 12761192]

Hu H, Shao LR, Chavoshy S, Gu N, Trieb M, Behrens R, Laake P, Pongs O, Knaus HG, Ottersen OP, Storm JF. Presynaptic Ca2+-activated K+ channels in glutamatergic hippocampal terminals and their role in spike repolarization and regulation of transmitter release. J Neurosci. 2001; 21:95859597. [PubMed: 11739569]

Jhou TC, Fields HL, Baxter MG, Saper CB, Holland PC. The rostromedial tegmental nucleus (RMTg), a GABAergic afferent to midbrain dopamine neurons, encodes aversive stimuli and inhibits motor responses. Neuron. 2009a; 61:786-800. [PubMed: 19285474]

Jhou TC, Geisler S, Marinelli M, Degarmo BA, Zahm DS. The mesopontine rostromedial tegmental nucleus: A structure targeted by the lateral habenula that projects to the ventral tegmental area of Tsai and substantia nigra compacta. J Comp Neurol. 2009b; 513:566-596. [PubMed: 19235216]

Jimenez-Rivera CA, Feliu-Mojer M, Vazquez-Torres R. Alpha-noradrenergic receptors modulate the development and expression of cocaine sensitization. Ann N Y Acad Sci. 2006; 1074:390-402. [PubMed: 17105937]

Johnson SW, North RA. Opioids excite dopamine neurons by hyperpolarization of local interneurons. J Neurosci. 1992a; 12:483-488. [PubMed: 1346804]

Johnson SW, North RA. Two types of neurone in the rat ventral tegmental area and their synaptic inputs. J Physiol. 1992b; 450:455-468. [PubMed: 1331427]

Jones BE, Halaris AE, McIlhany M, Moore RY. Ascending projections of the locus coeruleus in the rat. I. Axonal transport in central noradrenaline neurons. Brain Res. 1977; 127:1-21. [PubMed: 67877]

Kalivas PW, Churchill L, Klitenick MA. GABA and enkephalin projection from the nucleus accumbens and ventral pallidum to the ventral tegmental area. Neuroscience. 1993; 57:1047-1060. [PubMed: 7508582]

Kang JH, Toita R, Kim CW, Katayama Y. Protein kinase C (PKC) isozyme-specific substrates and their design. Biotechnol Adv. 2012; 30:1662-1672. [PubMed: 22841933]

Kauer JA. Learning mechanisms in addiction: synaptic plasticity in the ventral tegmental area as a result of exposure to drugs of abuse. Annu Rev Physiol. 2004; 66:447-475. [PubMed: 14977410]

Kawaguchi Y, Shindou T. Noradrenergic excitation and inhibition of GABAergic cell types in rat frontal cortex. J Neurosci. 1998; 18:6963-6976. [PubMed: 9712665]

Kim JY, Park CS. Potentiation of large-conductance calcium-activated potassium (BK $(\mathrm{Ca}))$ channels by a specific isoform of protein kinase C. Biochem Biophys Res Commun. 2008; 365:459-465. [PubMed: 17991423]

Lammel S, Ion DI, Roeper J, Malenka RC. Projection-specific modulation of dopamine neuron synapses by aversive and rewarding stimuli. Neuron. 2011; 70:855-862. [PubMed: 21658580]

Lammel S, Lim BK, Ran C, Huang KW, Betley MJ, Tye KM, Deisseroth K, Malenka RC. Inputspecific control of reward and aversion in the ventral tegmental area. Nature. 2012; 491:212-217. [PubMed: 23064228]

Lee US, Cui J. BK channel activation: structural and functional insights. Trends Neurosci. 2010; 33:415-423. [PubMed: 20663573]

Lei S, Deng PY, Porter JE, Shin HS. Adrenergic facilitation of GABAergic transmission in rat entorhinal cortex. J Neurophysiol. 2007; 98:2868-2877. [PubMed: 17804573]

Liprando LA, Miner LH, Blakely RD, Lewis DA, Sesack SR. Ultrastructural interactions between terminals expressing the norepinephrine transporter and dopamine neurons in the rat and monkey ventral tegmental area. Synapse. 2004; 52:233-244. [PubMed: 15103690]

Lobb CJ, Wilson CJ, Paladini CA. A dynamic role for GABA receptors on the firing pattern of midbrain dopaminergic neurons. J Neurophysiol. 2010; 104:403-413. [PubMed: 20445035]

Lobb CJ, Wilson CJ, Paladini CA. High-frequency, short-latency disinhibition bursting of midbrain dopaminergic neurons. J Neurophysiol. 2011; 105:2501-2511. [PubMed: 21367999]

Marek GJ, Aghajanian GK. Alpha 1B-adrenoceptor-mediated excitation of piriform cortical interneurons. Eur J Pharmacol. 1996; 305:95-100. [PubMed: 8813537] 
Margolis EB, Lock H, Hjelmstad GO, Fields HL. The ventral tegmental area revisited: is there an electrophysiological marker for dopaminergic neurons? J Physiol. 2006; 577:907-924. [PubMed: 16959856]

Marrion NV, Tavalin SJ. Selective activation of Ca2+-activated K+ channels by co-localized Ca2+ channels in hippocampal neurons. Nature. 1998; 395:900-905. [PubMed: 9804423]

Martire A, Tebano MT, Chiodi V, Ferreira SG, Cunha RA, Kofalvi A, Popoli P. Pre-synaptic adenosine A2A receptors control cannabinoid CB1 receptor-mediated inhibition of striatal glutamatergic neurotransmission. J Neurochem. 2011; 116:273-280. [PubMed: 21062287]

Mathew SS, Hablitz JJ. Calcium release via activation of presynaptic IP3 receptors contributes to kainate-induced IPSC facilitation in rat neocortex. Neuropharmacology. 2008; 55:106-116. [PubMed: 18508095]

Matsumoto M, Hikosaka O. Lateral habenula as a source of negative reward signals in dopamine neurons. Nature. 2007; 447:1111-1115. [PubMed: 17522629]

Mejias-Aponte CA, Drouin C, Aston-Jones G. Adrenergic and noradrenergic innervation of the midbrain ventral tegmental area and retrorubral field: prominent inputs from medullary homeostatic centers. J Neurosci. 2009; 29:3613-3626. [PubMed: 19295165]

Mitrano DA, Schroeder JP, Smith Y, Cortright JJ, Bubula N, Vezina P, Weinshenker D. alpha-1 Adrenergic receptors are localized on presynaptic elements in the nucleus accumbens and regulate mesolimbic dopamine transmission. Neuropsychopharmacology. 2012; 37:2161-2172. [PubMed: 22588352]

Morikawa H, Paladini CA. Dynamic regulation of midbrain dopamine neuron activity: intrinsic, synaptic, and plasticity mechanisms. Neuroscience. 2011; 198:95-111. [PubMed: 21872647]

Mouradian RD, Sessler FM, Waterhouse BD. Noradrenergic potentiation of excitatory transmitter action in cerebrocortical slices: evidence for mediation by an alpha 1 receptor-linked second messenger pathway. Brain Res. 1991; 546:83-95. [PubMed: 1677306]

Nugent FS, Kauer JA. LTP of GABAergic synapses in the ventral tegmental area and beyond. J Physiol. 2008; 586:1487-1493. [PubMed: 18079157]

Olive MF, Newton PM. Protein kinase C isozymes as regulators of sensitivity to and selfadministration of drugs of abuse-studies with genetically modified mice. Behav Pharmacol. 2010; 21:493-499. [PubMed: 20671547]

Omelchenko N, Sesack SR. Ultrastructural analysis of local collaterals of rat ventral tegmental area neurons: GABA phenotype and synapses onto dopamine and GABA cells. Synapse. 2009; 63:895906. [PubMed: 19582784]

Paladini CA, Tepper JM. GABA(A) and GABA(B) antagonists differentially affect the firing pattern of substantia nigra dopaminergic neurons in vivo. Synapse. 1999; 32:165-176. [PubMed: 10340627]

Paladini CA, Williams JT. Noradrenergic inhibition of midbrain dopamine neurons. J Neurosci. 2004; 24:4568-4575. [PubMed: 15140928]

Paxinos, G.; Watson, C. The rat brain in stereotaxic coordinates. Amsterdam; Boston: Academic Press/ Elsevier; 2007.

Raffaelli G, Saviane C, Mohajerani MH, Pedarzani P, Cherubini E. BK potassium channels control transmitter release at CA3-CA3 synapses in the rat hippocampus. J Physiol. 2004; 557:147-157. [PubMed: 15034127]

Reinhart PH, Levitan IB. Kinase and phosphatase activities intimately associated with a reconstituted calcium-dependent potassium channel. J Neurosci. 1995; 15:4572-4579. [PubMed: 7790924]

Rommelfanger KS, Mitrano DA, Smith Y, Weinshenker D. Light and electron microscopic localization of alpha-1 adrenergic receptor immunoreactivity in the rat striatum and ventral midbrain. Neuroscience. 2009; 158:1530-1540. [PubMed: 19068224]

Salgado H, Garcia-Oscos F, Patel A, Martinolich L, Nichols JA, Dinh L, Roychowdhury S, Tseng KY, Atzori M. Layer-specific noradrenergic modulation of inhibition in cortical layer II/III. Cereb Cortex. 2011; 21:212-221. [PubMed: 20466749]

Schultz W. Getting formal with dopamine and reward. Neuron. 2002; 36:241-263. [PubMed: 12383780] 
Sesack SR, Grace AA. Cortico-Basal Ganglia reward network: microcircuitry. Neuropsychopharmacology. 2010; 35:27-47. [PubMed: 19675534]

Tamura K, Manabe T, Kyogoku T, Andoh K, Ohshio G, Tobe T. Effect of postischemic reperfusion on the pancreas. Hepatogastroenterology. 1993; 40:452-456. [PubMed: 7505764]

Thastrup O, Cullen PJ, Drobak BK, Hanley MR, Dawson AP. Thapsigargin, a tumor promoter, discharges intracellular $\mathrm{Ca} 2+$ stores by specific inhibition of the endoplasmic reticulum $\mathrm{Ca} 2(+)-$ ATPase. Proc Natl Acad Sci U S A. 1990; 87:2466-2470. [PubMed: 2138778]

Ungerstedt U. Stereotaxic mapping of the monoamine pathways in the rat brain. Acta Physiol Scand Suppl. 1971; 367:1-48. [PubMed: 4109331]

van Zessen R, Phillips JL, Budygin EA, Stuber GD. Activation of VTA GABA neurons disrupts reward consumption. Neuron. 2012; 73:1184-1194. [PubMed: 22445345]

Vandael DH, Marcantoni A, Mahapatra S, Caro A, Ruth P, Zuccotti A, Knipper M, Carbone E. $\mathrm{Ca}(\mathrm{v}) 1.3$ and BK channels for timing and regulating cell firing. Mol Neurobiol. 2010; 42:185-198. [PubMed: 21088933]

Velasquez-Martinez MC, Vazquez-Torres R, Jimenez-Rivera CA. Activation of alpha1-adrenoceptors enhances glutamate release onto ventral tegmental area dopamine cells. Neuroscience. 2012; 216:18-30. [PubMed: 22542873]

Vergara C, Latorre R, Marrion NV, Adelman JP. Calcium-activated potassium channels. Curr Opin Neurobiol. 1998; 8:321-329. [PubMed: 9687354]

Wang ZW. Regulation of synaptic transmission by presynaptic CaMKII and BK channels. Mol Neurobiol. 2008; 38:153-166. [PubMed: 18759010]

Yuan WX, Chen SR, Chen H, Pan HL. Stimulation of alpha(1)-adrenoceptors reduces glutamatergic synaptic input from primary afferents through $\mathrm{GABA}(\mathrm{A})$ receptors and T-type $\mathrm{Ca}(2+)$ channels. Neuroscience. 2009; 158:1616-1624. [PubMed: 19068225]

Zeng L, Webster SV, Newton PM. The biology of protein kinase C. Adv Exp Med Biol. 2012; 740:639-661. [PubMed: 22453963]

Zucker RS. Short-term synaptic plasticity. Annu Rev Neurosci. 1989; 12:13-31. [PubMed: 2648947] 


\section{Highlights}

- a1-ARs activation at the presynaptic site decreases GABA release onto putative DA cells within VTA.

- Presynaptic a1-ARs activation modulates GABAergic inputs that affect VTA DA neurons excitability.

- a1-ARs effect might be heterosynaptically localized at GABAergic fibers terminating onto VTA-DA neurons. 

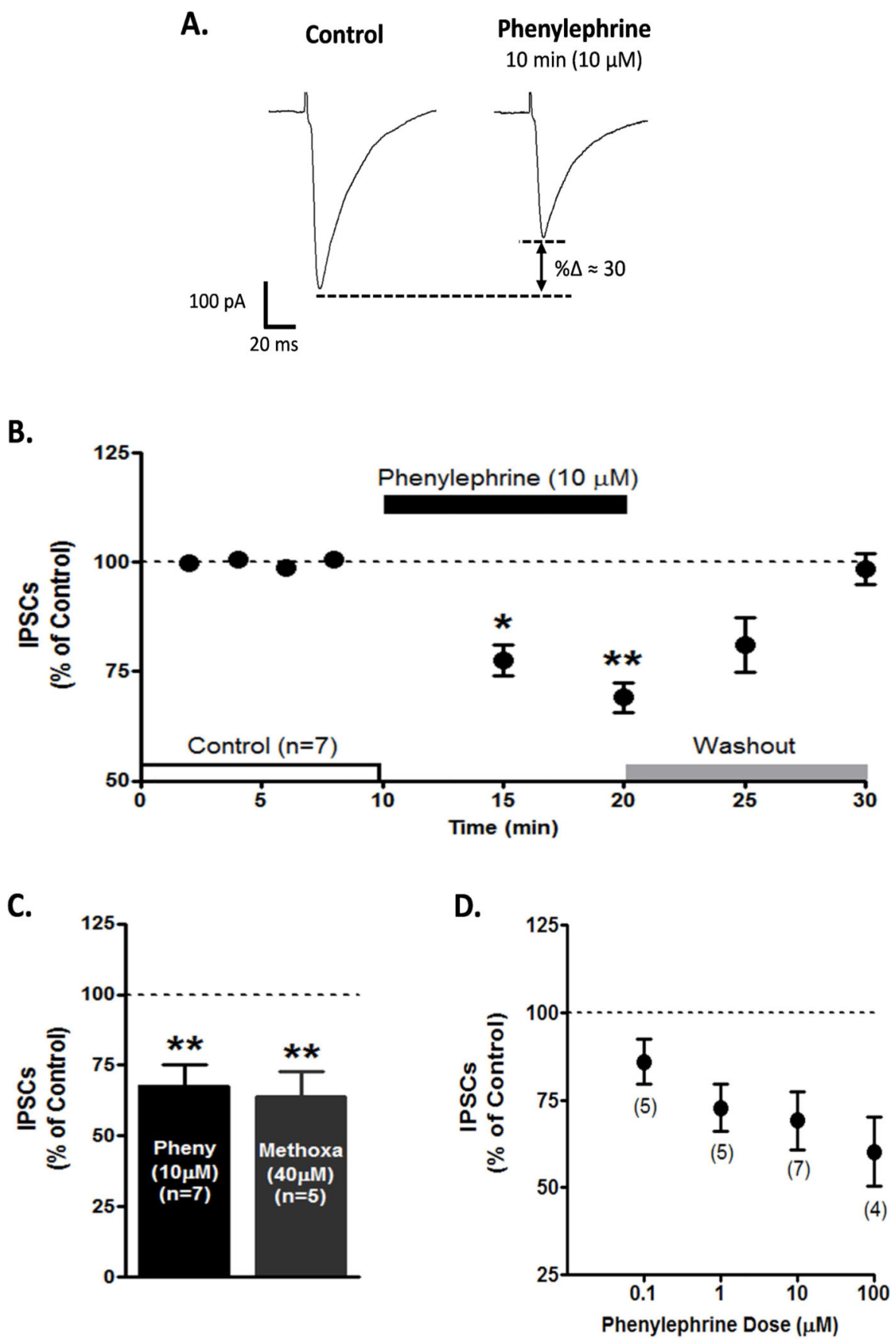

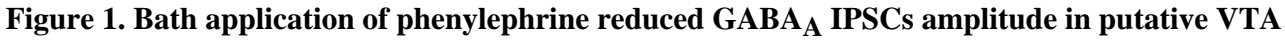
DA neurons

A. Representative recordings from the same cell, showing that phenylephrine's superfusion $(10 \mu \mathrm{m})$ induced a significant reduction in $\mathrm{GABA}_{\mathrm{A}}$ IPSCs amplitude in a putative VTA DA cell voltage clamped at $-70 \mathrm{mV}$. B. Summary time course of the effect of phenylephrine bath application on $\mathrm{GABA}_{\mathrm{A}}$ IPSCs amplitude recorded from 7 putative VTA DA neurons at 8 min of control ( 2 min intervals), 5 and 10 min phenylephrine $(10 \mu \mathrm{M})$ and 5 and $10 \mathrm{~min}$ washout. A 5 and 10 min phenylephrine application caused amplitude reduction of $\mathrm{GABA}_{\mathrm{A}}$ 
IPSCs. There was a rapid return to control levels upon phenylephrine removal. C. Bar graph showing that, on average, phenylephrine $(\mathrm{n}=7)$ and methoxamine $(\mathrm{n}=5)$ application resulted in a $\sim 30 \%$ decrease in $\mathrm{GABA}_{\mathrm{A}}$ IPSCs amplitude. D. Dose-response curve of phenylephrine's effect on GABA IPSCs. Phenylephrine-induced decrease was dosedependent over the concentration range of $0.1-100 \mu \mathrm{M}$. *p $<0.05$, ** $\mathrm{p}<0.01$; One-way ANOVA, Newman-Keuls post hoc. 

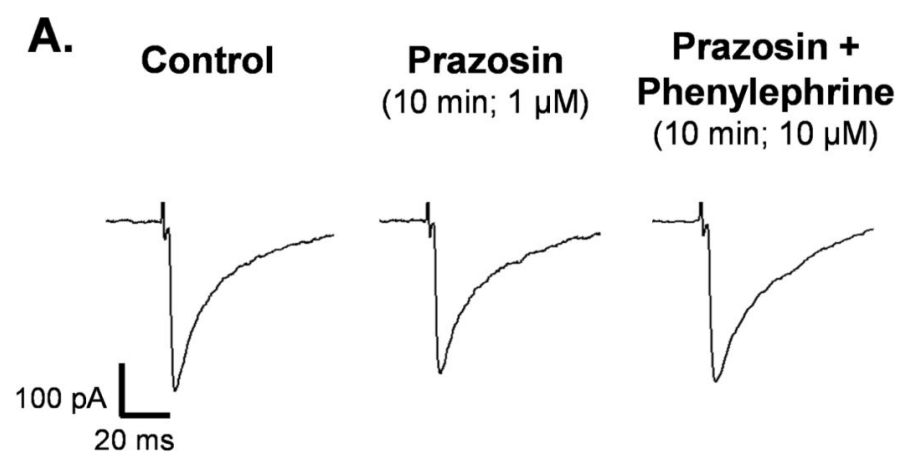
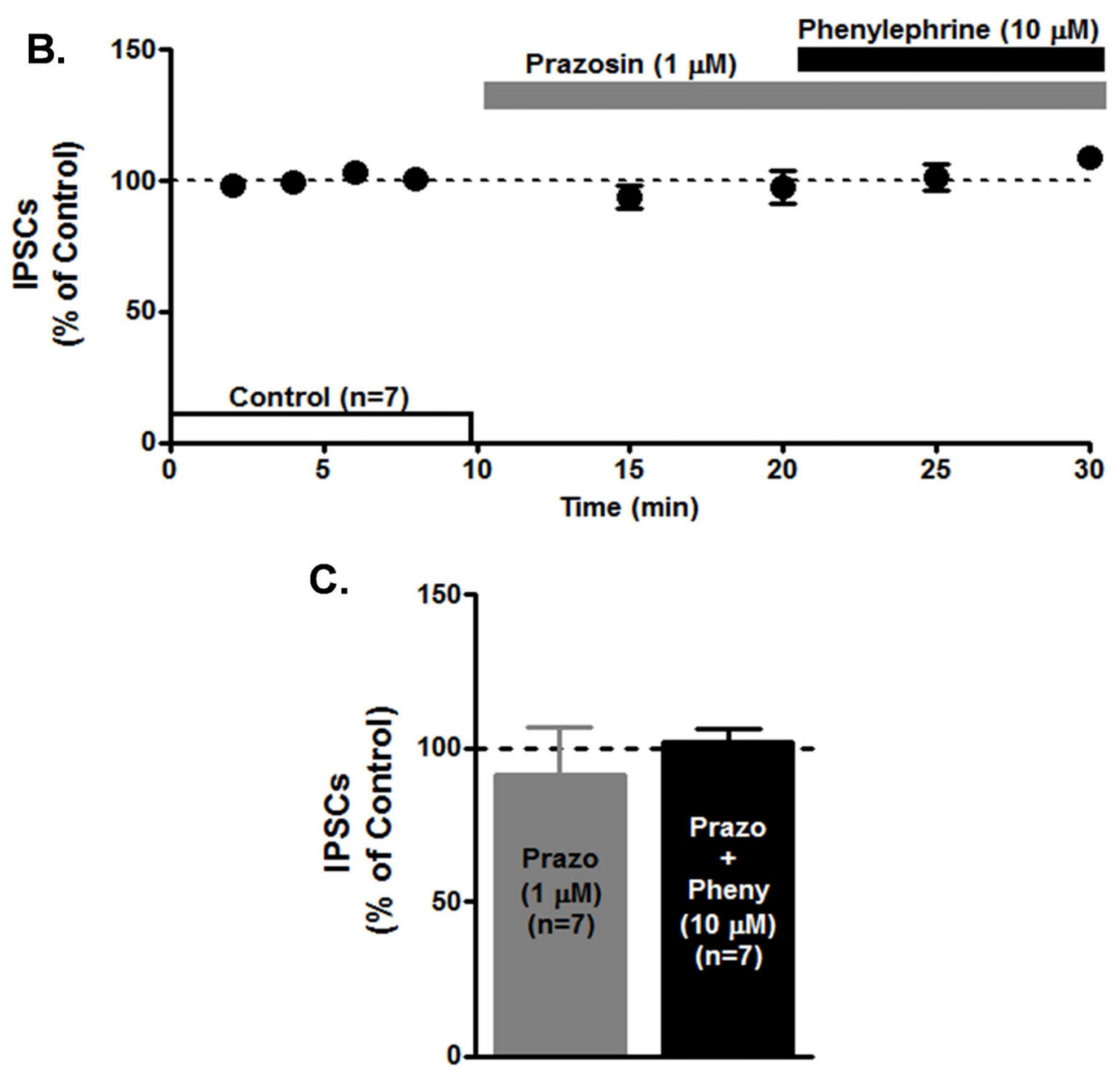

Figure 2. a1-AR antagonist, prazosin, blocks phenylephrine's effect on GABA $\mathrm{A}_{\mathrm{A}}$ IPSCs

A. Representative recordings from a neuron showing that the a1-AR antagonist prazosin (1

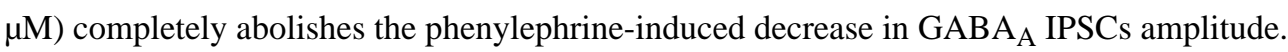
B. Prazosin superfusion leaves $\mathrm{GABA}_{\mathrm{A}}$ IPSCs amplitude unaltered. Phenylephrine $(10 \mu \mathrm{M})$ and prazosin $(1 \mu \mathrm{M})$ co-superfusion prevents phenylephrine-induced decrease of $\mathrm{GABA}_{\mathrm{A}}$ IPSCs amplitude. C. Summary illustrating the time course of prazosin actions. Note that prazosin alone has no effect on $\mathrm{GABA}_{\mathrm{A}}$ IPSCs amplitude. Each point represents the mean \pm SEM of $n=7$. 
A.

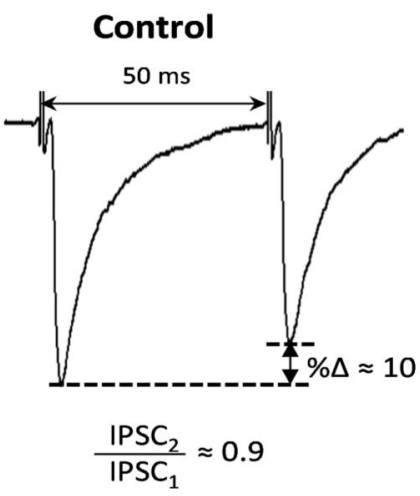

Phenylephrine

(10 $\mu \mathrm{M} ; 10 \mathrm{~min}$.)

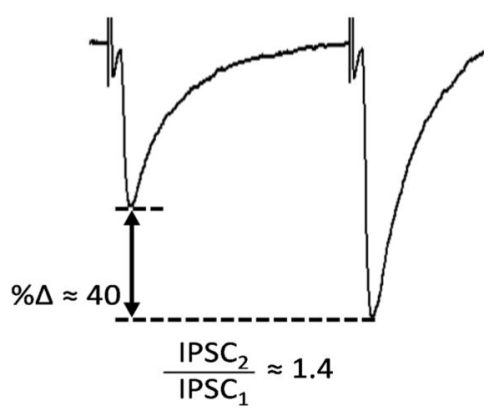

B.

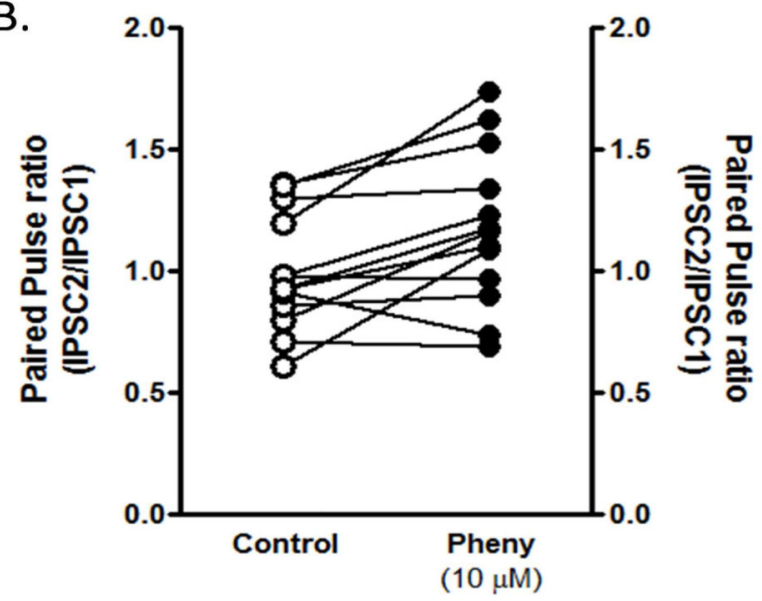

C.

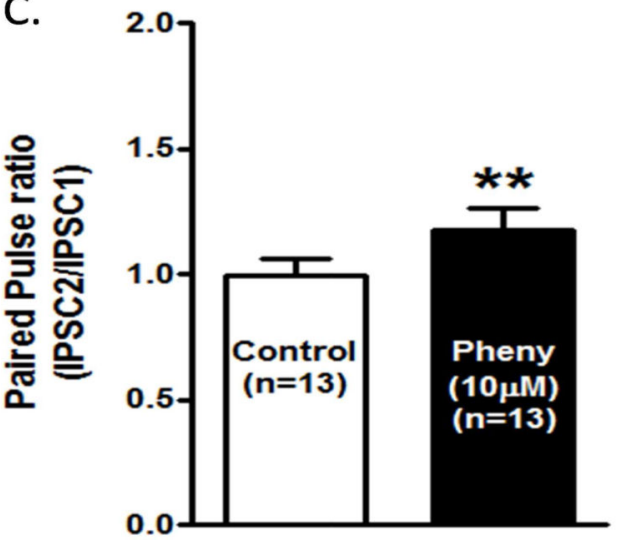

Figure 3. Phenylephrine increases paired-pulse ratio in putative VTA DA neurons

A. Representative recordings from a neuron illustrating that phenylephrine superfusion (10 $\mu \mathrm{M}, 10$ min application), induces a significant increase in paired pulse ratio (PPR = IPSC2/ IPSC1) in a putative VTA DA cell voltage clamp at a-70 mV. Time interval between consecutive EPSCs is $50 \mathrm{~ms}$. B. Bar graph showing that phenylephrine-induced increase in PPR is statistically significant ( $\mathrm{n}=13)$ C. Graph summary of the changes in PPR after $10 \mathrm{~min}$ phenylephrine $(10 \mu \mathrm{M})$ bath application. $* * \mathrm{p}<0.01$, paired t-test. 
A.
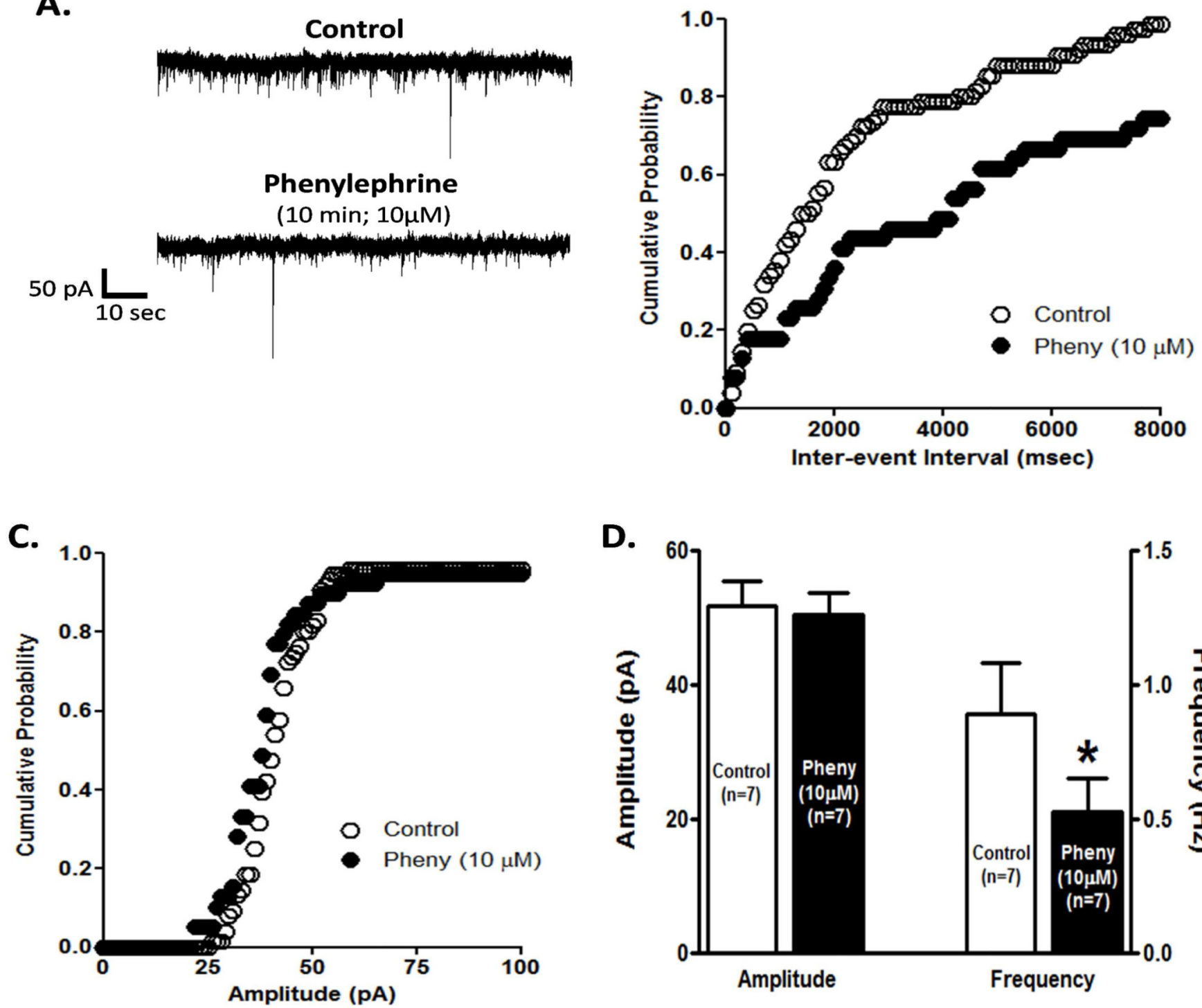

Figure 4. Phenylephrine decreases the frequency but not the amplitude of sIPSCs

A. Representative recordings from a cell illustrating that phenylephrine's application (10 $\mu \mathrm{M})$ decreases sIPSC frequency but not the amplitude. The cell was voltage clamped at -70 $\mathrm{mV}$ during the recordings. B. Phenylephrine's superfusion $(10 \mu \mathrm{M}, 10 \mathrm{~min}$ application) results in a shift to the right of the inter-event interval cumulative distribution $(\mathrm{K}-\mathrm{S}, \mathrm{p}<0.05)$ implying a decrease in sIPSCs frequency. The plot was constructed from the cell used in part A. C. Phenylephrine does not shift the sIPSCs amplitude cumulative distribution. The plot was constructed from the cell used in A. D. Summary graph showing that phenylephrine decreased the mean frequency without affecting the mean amplitude of sIPSCs $(n=7)$. * $p<$ 0.05 , paired $t$-test. 
A.

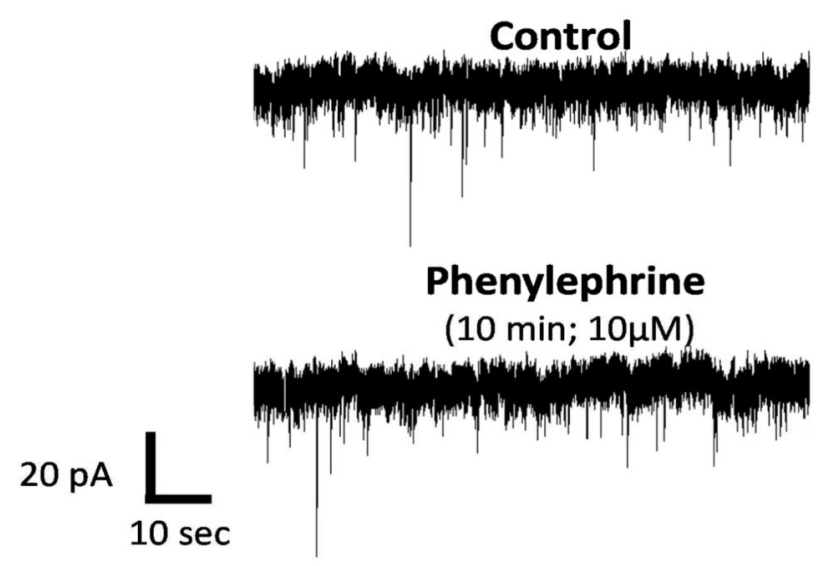

B.

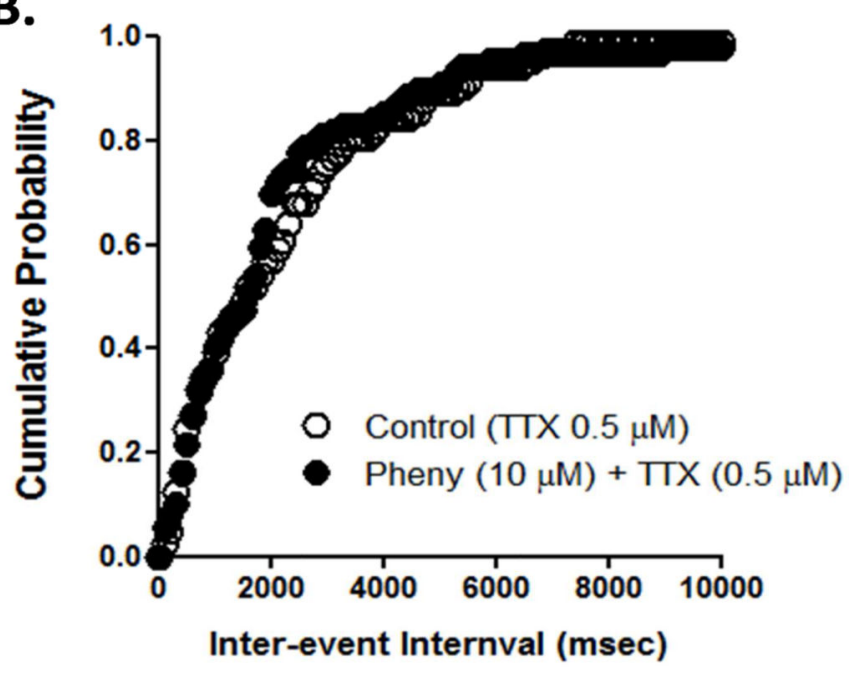

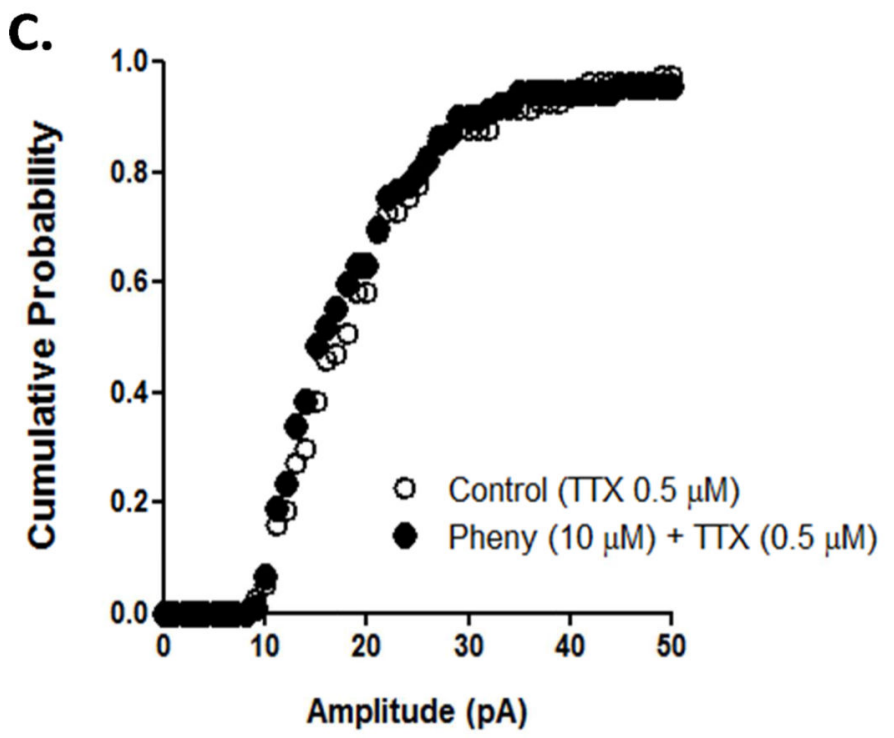

D.

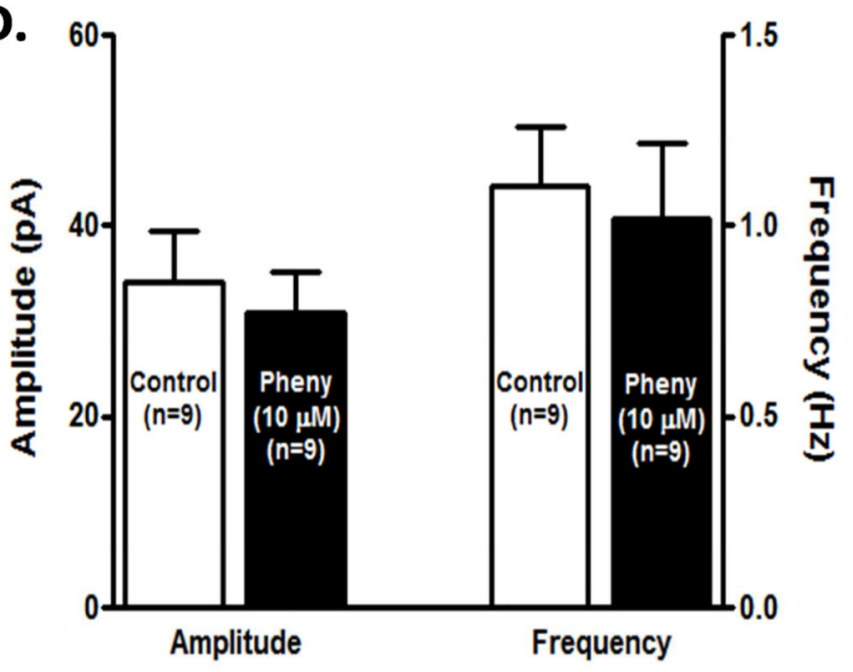

Figure 5. Phenylephrine had no effect on mIPSCs frequency or amplitude

A. Representative recordings from a neuron illustrating that in presence of TTX $(0.5 \mu \mathrm{M})$ phenylephrine $(10 \mu \mathrm{M})$ does not change the frequency or amplitude of mlPSCs. The neuron was voltage clamped at $-70 \mathrm{mV}$ during the recordings. B. Phenylephrine's superfusion (10 $\mu \mathrm{M}, 10 \mathrm{~min}$. application) does not shift the inter-event interval cumulative distribution of mIPSCs. The plot was constructed from the cell used in A. C. Phenylephrine does not shift the amplitude cumulative distribution of mIPSCs. The plot was constructed from the cell used in A. D. Summary graph showing that phenylephrine's superfusion in the presence of TTX had no effect on frequency or amplitude mIPSCs $(n=9)$. 

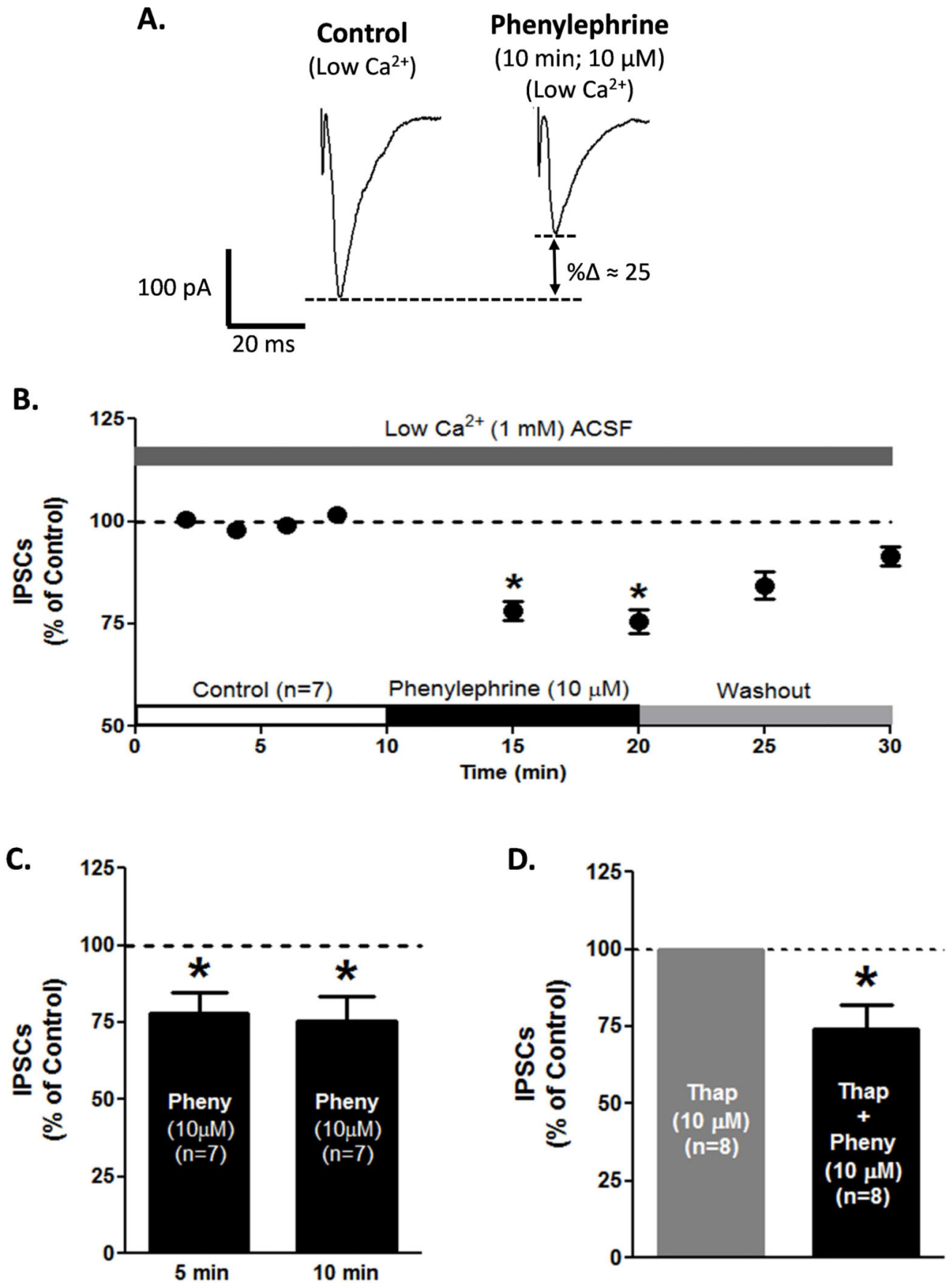

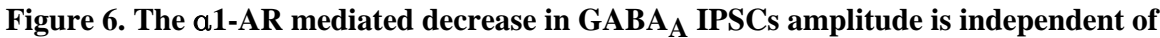
extracellular calcium concentration

A. Representative recordings from a neuron showing that low calcium ACSF $(1 \mathrm{mM}) \mathrm{did}$

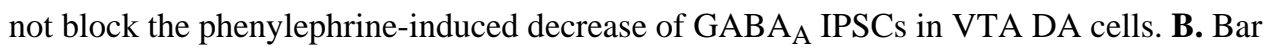
graph showing that application of phenylephrine on low $\mathrm{Ca}^{2+} \mathrm{ACSF}$, did not block phenylephrine-induced decrease of $\mathrm{GABA}_{\mathrm{A}}$ IPSCs $(10 \mu \mathrm{M}, 5$ and $10 \mathrm{~min})$. C. Summary time course of 7 neurons illustrating the population effects. D. Bar graph showing that application of phenylephrine $(10 \mu \mathrm{M}, 5$ and $10 \mathrm{~min})$ on thapsigargin pre-treated slices did 
not block phenylephrine-induce decrease of GABA $\mathrm{APSCs}$. * $\mathrm{p}<0.05$, One-way ANOVA, Newman-Keuls post-hoc. 
A.

Control Chelerythrine Chelerythrine +

$(10 \mathrm{~min} ; 1 \mu \mathrm{M}) \quad$ Phenylephrine

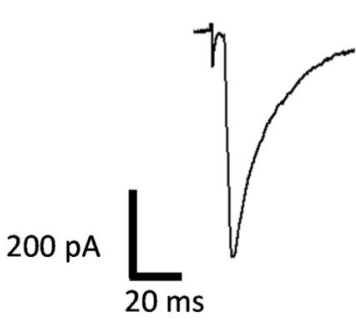

(10 min; $10 \mu \mathrm{M})$

B.
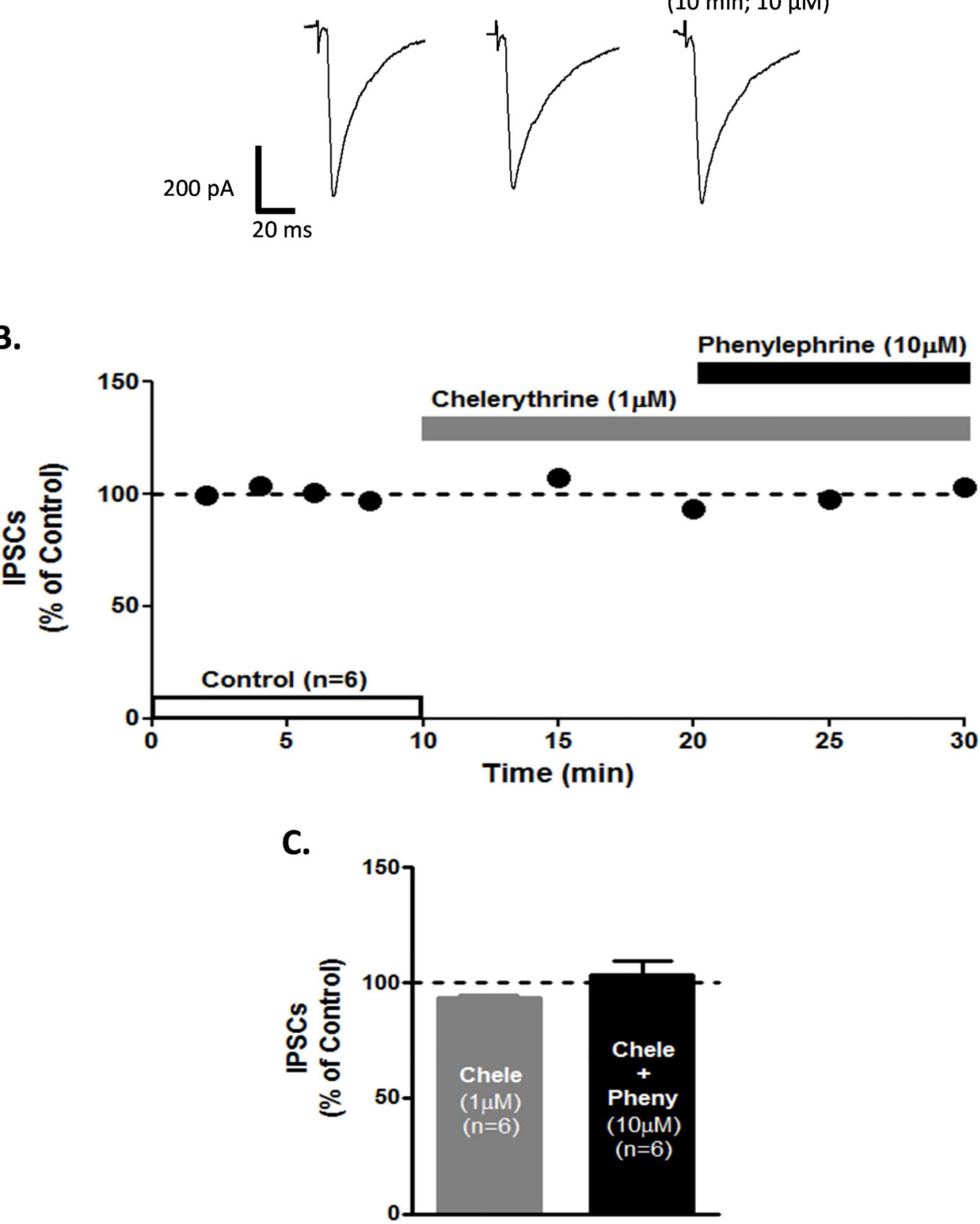

Figure 7. Involvement of the intracellular PKC signalling in the a1-AR mediated decrease in GABA A $_{\mathbf{A}}$ IPSCs amplitude

A. Representative recordings from a neuron showing that chelerythrine $(1 \mu \mathrm{M})$, a selective PKC inhibitor, completely prevents the phenylephrine-induced decrease of $\mathrm{GABA}_{\mathrm{A}}$ IPSCs in VTA DA neurons. B. Summary time course illustrating that PKC selective inhibitor chelerythrine $(1 \mu \mathrm{M})$ blocks the phenylephrine-induced decrease of $\mathrm{GABA}_{\mathrm{A}}$ IPSCs amplitude. Note that chelerythrine alone has no effect on $\mathrm{GABA}_{\mathrm{A}}$ IPSCs amplitude. Each point represents $n=7 \pm$ SEM. C. Bar graph showing that application of chelerythrine (Chele), 
completely abolished phenylephrine's effect $\left(10 \mu \mathrm{M} ; 10\right.$ min application) on $\mathrm{GABA}_{\mathrm{A}}$ IPSCs in VTA DA neurons. 
A.

Control

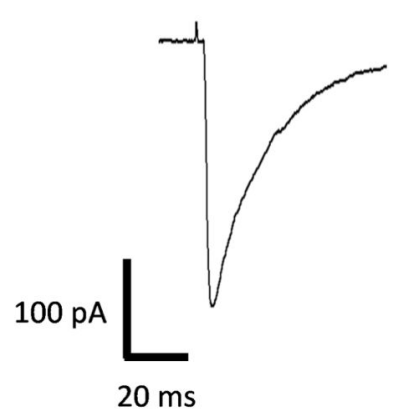

Paxilline

(10 min; $1 \mu \mathrm{M})$

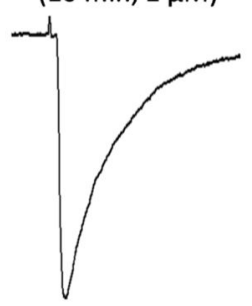

Phenylephrine

(10 $\mathrm{min} ; 10 \mu \mathrm{M})$

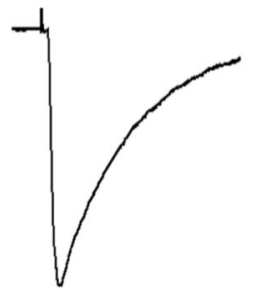

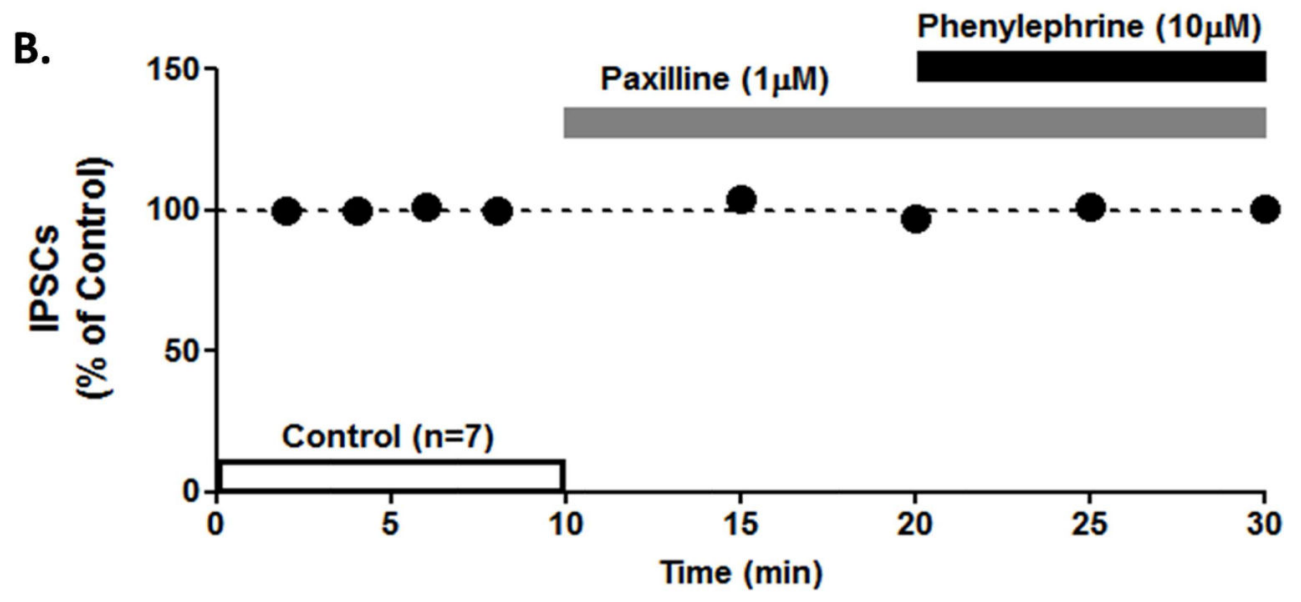

C.

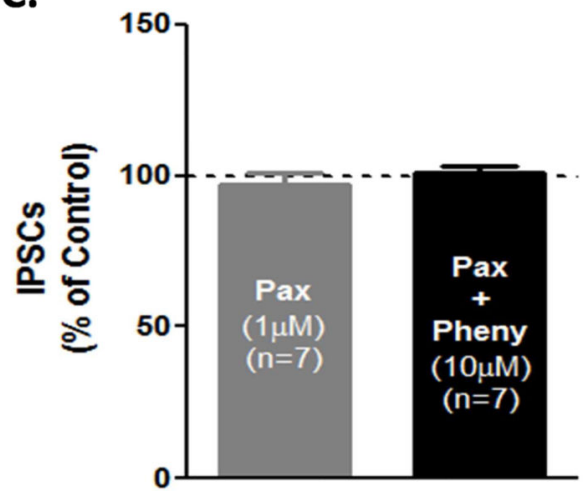

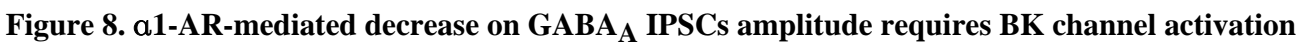
A. Representative recording from VTA DA neuron showing that paxilline $(1 \mu \mathrm{M}$, a selective BK channel inhibitor) prevents phenylephrine-induced decrease on $\mathrm{GABA}_{\mathrm{A}}$ IPSCs

amplitude. B. Summary time course illustrating that paxilline superfusion blocks phenylephrine decrease of $\mathrm{GABA}_{\mathrm{A}}$ IPSCs amplitude. Note that paxilline alone has no effect on $\mathrm{GABA}_{\mathrm{A}}$ IPSCs amplitude. Each point represents $\mathrm{n}=7 \pm$ SEM. C. Bar graph showing that paxilline application (Pax), completely abolished phenylephrine's effect $(10 \mu \mathrm{M} ; 10 \mathrm{~min}$ application) on $\mathrm{GABA}_{\mathrm{A}}$ IPSCs in VTA DA neurons. 


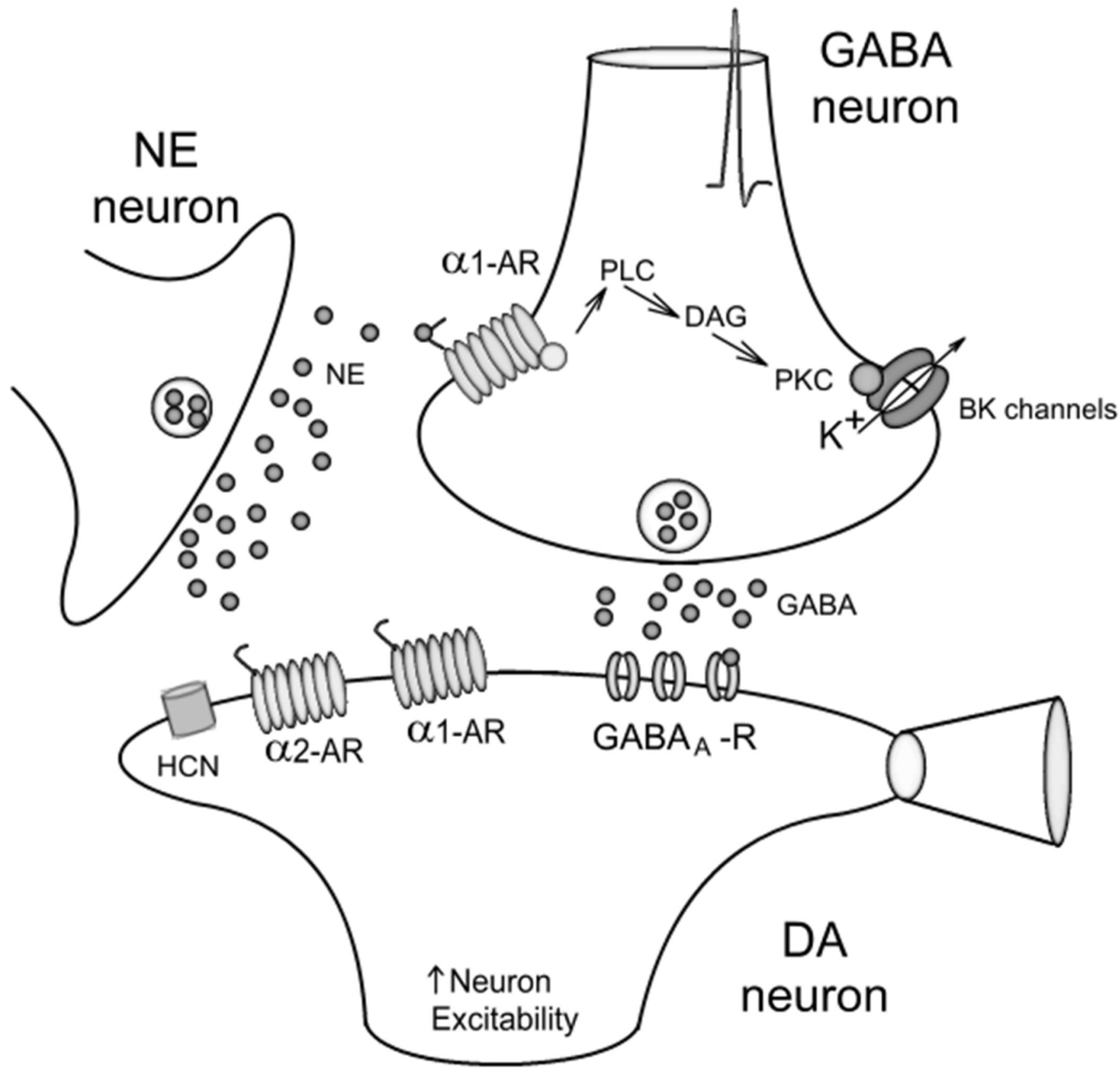

Figure 9. Schematic model to explain that a1-ARs presynaptic activation decrease GABA release onto VTA DA neurons by activation of PKC and BK channels

Stimulation of presynaptic a1-AR at inhibitory GABA terminals that project onto VTA DA neurons causes activation of PLC, via a Gq-mediated mechanism, resulting in DAG formation. The activated DAG stimulates a PKC phosphorylation, which may further increase BK channels activity hyperpolarizing the GABA terminal and therefore, decreasing GABA release. NE, norepinephrine; DA, dopamine; PLC, phospholipase C; DAG, diacylglycerol. 